\title{
Pola Pergerakan Komuting Sidoarjo-Surabaya
}

\author{
Teddy Kurniawan Bahar dan Ketut Dewi Martha Erli Handayeni \\ Departemen Perencanaan Wilayah dan Kota, Institut Teknologi Sepuluh Nopember (ITS) \\ e-mail:erli.martha@urplan.its.ac.id
}

\begin{abstract}
Abstrak-Kota Surabaya sebagai salah satu kota metropolitan tentunya telah dikenal sebagai pusat aktivitas sosial dan ekonomi di Jawa Timur. Semakin bertambahnya jumlah populasi penduduk dan lahan yang semakin berkurang menyebabkan sulitnya mencari tempat tinggal yang layak bagi penduduk yang bekerja di Surabaya. Fenomena urbanisasi menuju kawasan pinggiran perkotaan pun mulai terjadi, salah satu yang terdampak ialah Kabupaten Sidoarjo. Adanya ketidakcocokan tempat tinggal dan tempat bekerja mengindikasikan adanya spatial mismatch yang terjadi di Kabupaten Sidoarjo. Indikasi ini akan berdampak pada pola pergerakan komuting antara Sidoarjo menuju Surabaya. Penelitian ini akan mencari pola pergerakan komuting yang terjadi dan hubungan antara masing-masing variabel terhadap satu sama lain. Tahap analisis melalui dua tahap. Tahap pertama akan mendeskripsikan pergerakan yang terjadi dari Sidoarjo menuju Surabaya terkait tujuan perjalanan, jarak tempuh, waktu tempuh, biaya perjalanan dan moda kendaraan menggunakan analisis deskriptif. Tahap ketiga ialah menganalisa hubungan yang ada pada tiap variabel pergerakan komuting melalui analisis korelasi Pearson dan Crosstab. Penelitian menunjukkan bahwa terdapat 25 kecamatan di Kota Surabaya yang menjadi tujuan bekerja pelaku komuting dari Sidoarjo. Untuk nilai jarak tempuh tertinggi berasal dari Kecamatan Sukodono, waktu tempuh tertinggi dari Kecamatan Taman, biaya perjalanan tertinggi dari Kecamatan Sedati dan moda kendaraan didominasi oleh pengguna sepeda motor. Nilai jarak tempuh berkorelasi secara positif dengan waktu tempuh dan biaya perjalanan. Sedangkan moda kendaraan hanya memiliki hubungan dengan biaya perjalanan.
\end{abstract}

Kata Kunci-Kawasan Pinggiran-Pusat, Komuting.

\section{PENDAHULUAN}

$\mathrm{K}$ OTA Surabaya sebagai ibukota provinsi tentunya menjadi salah satu pusat kota aktivitas sosial maupun ekonomi di Jawa Timur. Predikat ini menjadikan Kota Surabaya sebagai destinasi penduduk Jawa Timur dalam mencari lapangan pekerjaan. Pada tahun 2006 diketahui terdapat 647.206 jiwa yang bekerja di Kota Surabaya dan di tahun 2016 terhitung 2.093.315 jiwa yang bekerja di Kota Surabaya. Tingginya kesempatan kerja di Surabaya akan meningkatkan pertumbuhan jumlah penduduk [1]. Pertumbuhan penduduk ini pun selain berdasarkan kelahiran juga dipengaruhi oleh migrasi penduduk dari kota/kabupaten lain. Pada tahun 2018 terdapat 39.005 jiwa penduduk pendatang dari luar Surabaya dan terdapat kenaikan jumlah penduduk sebesar 166.487 jiwa yang terdaftar di Surabaya [2]. Fenomena peningkatan jumlah penduduk ini dengan mempertimbangkan lahan luas Surabaya yang tidak berkembang maka akan berdampak secara langsung terhadap kepadatan penduduk Kota Surabaya. Peningkatan kepadatan penduduk tiap tahunnya mempunyai dampak langsung terhadap jumlah lahan untuk tempat tinggal di Kota Surabaya. Semakin langkanya lahan di Kota maka secara otomatis akan berdampak ke rata-rata harga pasar lahan. Hal tersebut dapat dilihat dari peningkatan yang terjadi dari tahun 2009-2011 pada beberapa titik observasi wilayah studi yaitu di Jalan Jenderal Ahmad Yani yaitu 77\%, Jalan Kusuma Bangsa sebesar 67\%, Jalan Ngagel Madya Raya sebesar 22\%, kemudian pada beberapa jalan lain mengalami kenaikan sekitar 0-13\% [3]. terbatasnya lahan untuk tempat tinggal di Kota Surabaya, tentunya lahan di kawasan pinggiran Kota Surabaya menjadi pilihan alternatif. Hal ini berarti terjadinya fenomena urban sprawl di kabupaten/kota yang berbatasan langsung dengan Surabaya diketahui urban sprawl termasif terjadi di Kabupaten Sidoarjo dibuktikan dengan jumlah penduduk terbesar berada di Kabupaten Sidoarjo yakni sebesar 2.217.059 jiwa [4]. Diketahui Kecamatan Waru, Kecamatan Sedati, Kecamatan Sukodono, Kecamatan Taman dan Kecamatan Gedangan merupakan lima kecamatan yang memiliki kepadatan permukiman paling tinggi di antara 18 kecamatan lainnya di Kabupaten Sidoarjo [5].

Berkembangnya permukiman di daerah pinggiran mengakibatkan meningkatnya jumlah pergerakan penduduk dari pinggiran menuju pusat kota. Pergerakan ini pun terjadi setiap hari, yang berarti pergerakan yang terjadi ialah termasuk dalam pergerakan komuting. Pergerakan Komuting merupakan sebuah kegiatan perpindahan yang dilakukan secara berkala dan terjadwal. Pelaku dari komuting ini disebut sebagai komuter yaitu seseorang yang bepergian ke suatu tempat untuk bekerja dan kembali ke tempat tinggalnya setiap hari [6]. Untuk lebih mudah dalam mendefinisikannya, suatu perjalanan harus memiliki Jarak minimal lebih dari 16,2 $\mathrm{km}$ sehingga bisa dikatakan sebagai pergerakan komuting [7]. Tercatat ada 211.075 penduduk yang bekerja di luar Kabupaten Sidoarjo dan 67\% diantaranya bertujuan menuju Kota Surabaya [8]. Kapasitas Jalan Ahmad Yani sebagai jalan fungsi arteri primer yang menghubungkan Kabupaten Sidoarjo dengan Kota Surabaya, pada waktu Peak Hour ialah $6.053 \mathrm{smp} / \mathrm{jam}$ yang jika dikonversikan ke degree of saturation termasuk dalam Tingkat F (Sangat buruk) [9]. Dari fakta ini bisa dikatakan pergerakan komuting yang terjadi dari Kabupaten Sidoarjo menuju Kota Surabaya sangatlah tinggi dan akan menimbulkan dampak yang cukup signifikan terhadap transportasi di Kota Surabaya.

\section{METODOLOGI PENELITIAN}

\section{A. Variabel Penelitian}

Penelitian ini merupakan jenis penelitian deskriptif kuantitatif. Penelitian ini memberikan informasi dan analisis data yang menekankan pada data-data numerik yang diolah menggunakan data statistik [10]. Penentuan variabel penelitian pada pelaku pergerakan komuting dari Kabupaten Sidoarjo menuju Kota Surabaya berdasarkan dari hasil sintesa pustaka ditunjukkan pada Tabel 1.

\section{B. Metode Pengumpulan Data}

Pengambilan sampel penelitian ini dilakukan dengan menggunakan teknik purposive sampling. Kriteria responden 
Tabel 1.

Variabel Penelitian

\begin{tabular}{ll}
\hline Indikator & Variabel \\
\hline Kependudukan & Lokasi Tempat Tinggal \\
Ketenagakerjaan & Lokasi Tempat Bekerja \\
Pola Komuting & Jarak Tempuh \\
& Waktu Tempuh \\
& Biaya Perjalanan \\
& Moda Kendaraan \\
\hline
\end{tabular}

Tabel 2.

Jumlah Sampel tiap Kecamatan

\begin{tabular}{lc}
\multicolumn{2}{c}{ Jumlah Sampel tiap Kecamatan } \\
\hline \hline \multicolumn{1}{c}{ Kecamatan } & Jumlah Sampel \\
\hline Gedangan & 25 \\
Sedati & 8 \\
Sukodono & 16 \\
Taman & 53 \\
Waru & 53 \\
Jumlah & 155 \\
\hline \hline
\end{tabular}

penduduk Kabupaten Sidoarjo yang bertempat tinggal di antara Kecamatan Gedangan, Kecamatan Sedati, Kecamatan Sukodono, Kecamatan Taman dan Kecamatan Waru. Pada perumusan sampel, peneliti menggunakan pendekatan random sampling menyebarkan kuisioner secara offline melalui penyebaran secara door to door dan online menggunakan online form yang disebar melalui beberapa media sosial untuk lima kecamatan. Jumlah sampel berbeda tiap kecamatan yang didapatkan berdasarkan rasio populasi dari masing-masing kecamatan. (Tabel 2)

Pengambilan data primer dilakukan dengan melalui observasi dan meyebarkan kuisioner kepada responden, sedangkan data sekunder dilakukan melalui survey instansi (Kantor Kecamatan, Badan Pusat Statistik dan Dispendukcapil Sidoarjo).

\section{Metode Analisis}

Untuk mencapai tujuan penelitian ini yaitu mengidentifikasi pola pergerakan komuting yang terjadi di Sidoarjo-Surabaya, maka digunakan beberapa metode dan teknik analisis dalam setiap tahapan penelitian. Tahap pertama yaitu menggunakan metode statistic deskriptif untuk mencari pola perjalanan pelaku komuting tahap kedua menggunakan 2 metode yaitu analisa korelasi Pearson Bivariate dan Crosstab untuk mencari keterkaitan antara masing-masing variabel pergerakan komuting. Penghitungan tingkat korelasi antara variabel-variabel yang telah diperoleh menggunakan rumus persamaan analisa korelasi Pearson [11]. Uji analisa korelasi R Pearson ini akan digunakan untuk mencari hubungan antara variable commuting distance, commuting time dan commuting cost. Alasan utama memakai korelasi Pearson ialah mempertimbangkan data yang akan diperoleh dalam observasi ialah data skala rasio. Dari hasil $r$ hitung, dapat diinterpretasikan menjadi suatu pernyataan terkait hubungan keterkaitan antara kedua variabel tersebut, hal yang menjadi ketentuannya ialah :

1. Jika $r$ hitung (Pearson) $>\mathrm{r}$ tabel maka ada hubungan korelasi antara 2 variabel

2. Jika $r$ hitung (Pearson) $<\mathrm{r}$ tabel maka tidak ada hubungan korelasi antara 2 variabel

Metode crosstab adalah suatu metode untuk mentabulasikan beberapa variabel yang berbeda ke dalam suatu matriks [12]. Tujuan penggunaan teknik analisis crosstab dalam penelitian ini adalah untuk mengetahui hubungan karakteristik pemilihan moda kendaraan komuter (commuting mode) terhadap variabel pergerakan komuting

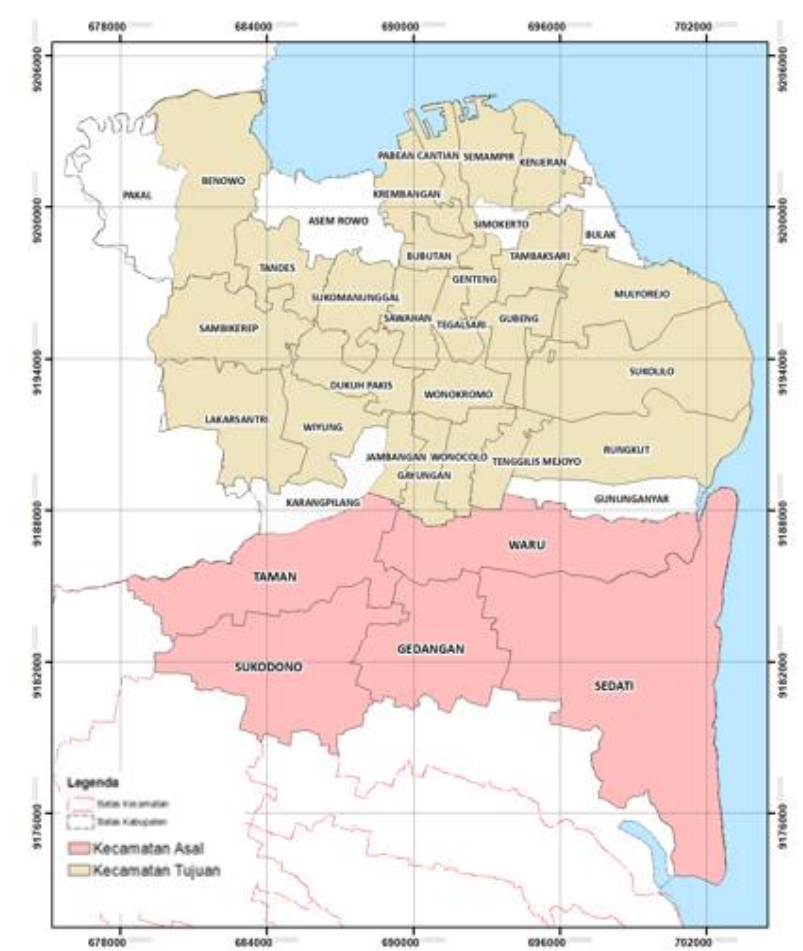

Gambar 1. Peta Persebaran Kecamatan Tujuan Pelaku Komuting.

lain di antaranya jarak tempuh, waktu tempuh dan biaya perjalanan. Dalam teknik analisis tabulasi silang ini terdapat indikator statistik berupa Chi-Square yang digunakan untuk menguji ada tidaknya hubungan/keterkaitan variabel-variabel yang dinyatakan dalam baris dan kolom. Hasil dari harga chisquare akan menjadi pertimbangan dalam menentukan hipotesa yang dinyatakan sebelum melakukan analisa. Penafsiran yang dilakukan merujuk pada ketentuan :

$\chi \geq 0,05$ Ho diterima dan Ha ditolak

$\chi \leq 0,05$ Ha diterima dan Ho ditolak

Keterangan :

Ho : Tidak terdapat hubungan yang signifikan antara variabel 1 dengan variabel 2

Ha : Terdapat hubungan yang signifikan antara variabel 1 dengan variabel 2

\section{HASIL DAN PEMBAHASAN}

\section{A. Identifikasi pola perjalanan bagi pelaku komuting} Sidoarjo-Surabaya

Berdasarkan hasil survei yang telah dilakukan, diperoleh 155 data sampel berupa Identitas, Alamat rumah di Sidoarjo, Lokasi bekerja di Surabaya, Jarak perjalanan yang ditempuh, Lama waktu perjalanan yang ditempuh, Biaya perjalanan dan Moda kendaraan yang paling sering digunakan. Dari hasil observasi tersebut akan diolah menjadi data pola pergerakan komuting Sidoarjo-Surabaya. (Gambar 1)

\section{1) Tujuan Perjalanan Pergerakan Komuting}

Dalam sampling data yang dilakukan, tidak ada batasan tujuan lokasi yang menjadi tujuan pelaku komuting dari wilayah studi ke Kota Surabaya. Hal ini mengakibatkan distribusi yang acak terkait tujuan perjalanan komuting dari masing-masing kecamatan yang telah disurvei. Total ada 25 kecamatan yang menjadi tujuan pelaku komuter dari 31 kecamatan yang ada di Kota Surabaya. Jumlah dari pelaku komuter yang menuju masing-masing kecamatan pun berbeda jumlahnya. Rekapitulasinya dapat dilihat pada Tabel 3 dan Gambar 2. 
2) Jarak tempuh pergerakan komuting

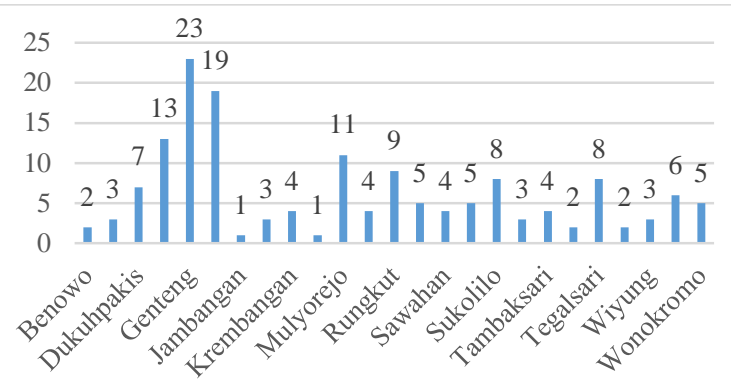

Gambar 2. Grafik Distribusi Tujuan Pelaku Komuting.

Tabel 3 .

Tujuan Perjalanan Pelaku Komuting berdasarkan Kecamatan Asal

\begin{tabular}{|c|c|c|c|c|c|}
\hline \multirow{2}{*}{$\begin{array}{l}\text { Kecamatan } \\
\text { Tujuan }\end{array}$} & \multicolumn{5}{|c|}{ Kecamatan Asal } \\
\hline & Gedangan & Sedati & Sukodono & Taman & Waru \\
\hline Benowo & 0 & 0 & 0 & 2 & 0 \\
\hline Bubutan & 0 & 0 & 1 & 2 & 0 \\
\hline Dukuhpakis & 0 & 0 & 1 & 3 & 3 \\
\hline Gayungan & 2 & 1 & 2 & 3 & 5 \\
\hline Genteng & 4 & 1 & 0 & 8 & 10 \\
\hline Gubeng & 3 & 1 & 2 & 3 & 10 \\
\hline Jambangan & 1 & 0 & 0 & 0 & 0 \\
\hline Kenjeran & 1 & 0 & 0 & 2 & 0 \\
\hline Krembangan & 1 & 0 & 2 & 0 & 1 \\
\hline Lakarsantri & 0 & 0 & 0 & 1 & 0 \\
\hline Mulyorejo & 1 & 2 & 3 & 1 & 4 \\
\hline Pabean & 0 & 0 & 1 & 3 & 0 \\
\hline \multicolumn{6}{|l|}{ Cantian } \\
\hline Rungkut & 2 & 1 & 0 & 6 & 0 \\
\hline Sambikerep & 0 & 1 & 0 & 2 & 2 \\
\hline Sawahan & 0 & 0 & 2 & 2 & 0 \\
\hline Semampir & 2 & 0 & 0 & 3 & 0 \\
\hline Sukolilo & 0 & 0 & 2 & 1 & 5 \\
\hline Suko & 0 & 0 & 0 & 2 & 1 \\
\hline manunggal & & & & & \\
\hline Tambaksari & 2 & 0 & 0 & 1 & 1 \\
\hline Tandes & 0 & 0 & 0 & 2 & 0 \\
\hline Tegalsari & 2 & 1 & 0 & 0 & 5 \\
\hline $\begin{array}{l}\text { Tenggilis } \\
\text { mejoyo }\end{array}$ & 1 & 0 & 0 & 0 & 1 \\
\hline Wiyung & 2 & 0 & 0 & 1 & 0 \\
\hline Wonocolo & 0 & 0 & 0 & 3 & 3 \\
\hline Wonokromo & 1 & 0 & 0 & 2 & 2 \\
\hline Jumlah & 25 & 8 & 16 & 53 & 53 \\
\hline
\end{tabular}

Jarak pergerakan komuting atau juga bisa disebut commuting distance merupakan substansi yang krusial dari pola pergerakan komuting. Suatu perjalanan dapat diklasifikasikan sebagai pergerakan komuting merujuk kepada jarak yang ditempuh, sebagai unit satuannya. Tabel 4 merupakan jumlah pelaku komuting berdasarkan klasifikasi jarak yang telah ditentukan.

\section{3) Waktu tempuh pergerakan komuting}

Waktu tempuh pergerakan komuting atau bisa disebut commuting time adalah periode waktu yang diperlukan dalam perjalanan komuting dari asal menuju tujuan tempat pelaku berkegiatan. Tabel 5 merupakan jumlah pelaku komuting berdasarkan klasifikasi waktu yang telah ditentukan.

\section{4) Biaya Perjalanan Pergerakan Komuting}

Biaya perjalanan atau bisa disebut commuting cost ialah biaya yang dihubungkan dengan tujuan membantu kegiatan perjalanan dari asal hingga tujuan perjalanan komuting. Biaya yang dimaksud dapat berupa biaya bahan bakar kendaraan, iuran kendaraan umum, iuran penggunaan jalan tol, biaya sewa kendaraan dsb. Tabel 6 merupakan jumlah pelaku komuting berdasarkan klasifikasi jumlah biaya yang telah ditentukan.

Moda Kendaraan Pergerakan KomutingModa kendaraan atau bisa disebut Mode of Transport ialah istilah yang
Tabel 4

Jarak Tempuh Pelaku Komuting Sidoarjo-Surabaya

\begin{tabular}{cccccc}
\hline \hline Jarak $(\mathrm{km})$ & \multicolumn{5}{c}{ Kecamatan Asal } \\
\cline { 2 - 6 } & Gedangan & Sedati & Sukodono & Taman & Waru \\
\hline$<5$ & 1 & 0 & 0 & 0 & 0 \\
$5-10$ & 1 & 0 & 0 & 3 & 6 \\
$11-15$ & 3 & 1 & 3 & 12 & 31 \\
$16-20$ & 15 & 5 & 1 & 22 & 15 \\
$>20$ & 5 & 2 & 12 & 16 & 1 \\
Jumlah & 25 & 8 & 16 & 53 & 53 \\
\hline \hline
\end{tabular}

Tabel 5

Waktu Tempuh Pelaku Komuting Sidoarjo-Surabaya

\begin{tabular}{cccccc}
\hline \hline Waktu & \multicolumn{5}{c}{ Kecamatan Asal } \\
\cline { 2 - 6 } (menit) & Gedangan & Sedati & Sukodono & Taman & Waru \\
\hline $0-10$ & 2 & 0 & 0 & 1 & 3 \\
$11-20$ & 2 & 1 & 1 & 8 & 7 \\
$21-30$ & 8 & 4 & 7 & 17 & 16 \\
$31-40$ & 7 & 1 & 1 & 9 & 12 \\
$41-50$ & 4 & 1 & 4 & 11 & 11 \\
$>50$ & 2 & 1 & 3 & 7 & 4 \\
Jumlah & 25 & 8 & 16 & 53 & 53 \\
\hline \hline
\end{tabular}

Tabel 6.

Biaya Perjalanan Pelaku Komuting Sidoarjo-Surabaya

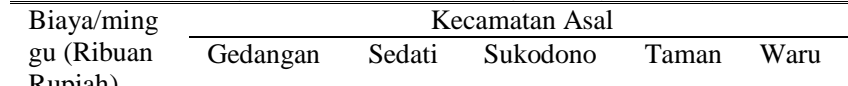

\begin{tabular}{cccccc}
\hline$<20$ & 2 & 0 & 3 & 1 & 2 \\
$21-40$ & 7 & 2 & 1 & 19 & 16 \\
$41-60$ & 10 & 3 & 7 & 18 & 22 \\
$61-80$ & 1 & 1 & 0 & 9 & 1 \\
$81-100$ & 1 & 0 & 0 & 1 & 0 \\
$>100$ & 4 & 2 & 5 & 5 & 12 \\
Jumlah & 25 & 8 & 16 & 53 & 53 \\
\hline \hline
\end{tabular}

Tabel 7.

Moda Kendaraan Pelaku Komuting Sidoarjo-Surabaya

\begin{tabular}{cccccc}
\hline \hline Moda & \multicolumn{5}{c}{ Kecamatan Asal } \\
\cline { 2 - 6 } & Gedangan & Sedati & Sukodono & Taman & Waru \\
\hline Motor & 22 & 6 & 14 & 48 & 41 \\
Mobil & 2 & 2 & 1 & 5 & 11 \\
Angkutan & 0 & 0 & 1 & 0 & 1 \\
Umum & & & & & 53 \\
Jumlah & 24 & 8 & 16 & 53 & 53 \\
\hline \hline
\end{tabular}

digunakan untuk merepresentasikan cara-cara yang dapat digunakan dalam melakukan perpindahan manusia ataupun barang. Jika dalam konteks pergerakan komuting dapat disebut sebagai commuting mode yaitu cara-cara yang dapat digunakan dalam melakukan perjalanan komuting. Batasan perjalanan komuting yang dilakukan secara rutin memperjelas bahwa moda kendaraan harus berklasifikasi menggunakan kendaraan bermotor. (Tabel 7)

\section{B. Analisa Hubungan antara variabel Pergerakan Komuting}

Pada tahap berikutnya akan dilakukan analisa yang mencari hubungan di antara masing masing variabel pergerakan komuting yaitu jarak tempuh, waktu, biaya perjalanan dan moda kendaraan. Metode yang digunakan ialah analisis crosstab dan korelasi Pearson. Pencarian hubungan variabel jarak tempuh, waktu dan biaya perjalanan diolah menggunakan analisis korelasi Pearson. Lalu berikutnya dilakukan analisa crosstab yang akan mencari hubungan variabel moda kendaraan terhadap variabelvariabel lainnya.

Tabel 8 merupakan hasil analisa korelasi Pearson menggunakan SPSS Statistics 17.0. Dari hasil yang telah didapatkan ditemukan berbagai interpretasi yang cukup 
Tabel 8 .

Analisa Korelasi Pearson Bivariate Variabel Pergerakan Komuting

\begin{tabular}{|c|c|c|c|c|}
\hline & & Jarak & Waktu & Biaya \\
\hline \multirow{3}{*}{ 密 } & Pearson Correlation & 1 & $.698^{* *}$ & $.207^{* *}$ \\
\hline & Sig. (2-tailed) & & .000 & .010 \\
\hline & $\mathrm{N}$ & 155 & 155 & 155 \\
\hline \multirow{3}{*}{ 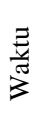 } & Pearson Correlation & $.698^{* *}$ & 1 & $.237^{* *}$ \\
\hline & Sig. (2-tailed) & .000 & & .003 \\
\hline & $\mathrm{N}$ & 155 & 155 & 155 \\
\hline \multirow{3}{*}{$\overbrace{\bar{n}}^{\pi}$} & Pearson Correlation & $.207^{* *}$ & $.237^{* *}$ & 1 \\
\hline & Sig. (2-tailed) & .010 & .003 & \\
\hline & $\mathrm{N}$ & 155 & 155 & 155 \\
\hline
\end{tabular}

Tabel 9.

Analisa Crosstab Jarak dengan Moda Kendaraan

\begin{tabular}{|c|c|c|c|c|c|}
\hline \multirow{2}{*}{ - } & & \multicolumn{3}{|c|}{ Moda Kendaraan } & \multirow[b]{2}{*}{ Total } \\
\hline & & Angkutan Umum & Mobil & Motor & \\
\hline \multirow{4}{*}{$\underbrace{10-20}$} & Count & 0 & 0 & 9 & 9 \\
\hline & $\%$ of Total & $.0 \%$ & $.0 \%$ & $5.8 \%$ & $5.8 \%$ \\
\hline & Count & 1 & 17 & 92 & 110 \\
\hline & $\%$ of Total & $.6 \%$ & $11.0 \%$ & $59.4 \%$ & $71.0 \%$ \\
\hline \multirow[t]{2}{*}{$>20$} & Count & 1 & 4 & 31 & 36 \\
\hline & $\%$ of Total & $.6 \%$ & $2.6 \%$ & $20.0 \%$ & $23.2 \%$ \\
\hline \multirow[t]{7}{*}{ Total } & Count & 2 & 21 & 132 & 155 \\
\hline & $\%$ of Total & $1.3 \%$ & $13.5 \%$ & $85.2 \%$ & $100.0 \%$ \\
\hline & \multicolumn{5}{|c|}{ Chi-Square Tests } \\
\hline & & Value & df & \multicolumn{2}{|c|}{ Asymp. Sig. (2-sided) } \\
\hline & Pearson Chi-Square & $2.796^{\mathrm{a}}$ & 4 & \multicolumn{2}{|c|}{.593} \\
\hline & Likelihood Ratio & 3.976 & 4 & \multicolumn{2}{|c|}{409} \\
\hline & $\mathrm{N}$ of Valid Cases & 155 & & & \\
\hline
\end{tabular}

bervariasi satu sama lain. Penjelasannya adalah sebagai berikut:

a. Variabel Jarak dengan Waktu terdapat hubungan yang signifikan di antara kedua variabel dengan nilai signifikansi 0,000. Tingkat korelasi antara kedua variabel tergolong positif kuat dengan angka 0,698. Artinya semakin tinggi nilai variabel jarak maka semakin tinggi pula nilai variabel waktu (dan sebaliknya).

b. Variabel Jarak dengan Biaya terdapat hubungan yang signifikan di antara kedua variabel dengan nilai signifikansi 0,010. Tingkat korelasi antara kedua variabel tergolong positif lemah dengan angka 0,207. Artinya semakin tinggi nilai variabel jarak maka semakin tinggi pula nilai variabel biaya (dan sebaliknya).

c. Variabel Waktu dengan Biaya terdapat hubungan yang signifikan di antara kedua variabel dengan nilai signifikansi 0,003. Tingkat korelasi antara kedua variabel tergolong lemah positif dengan angka 0,237. Artinya semakin tinggi nilai variabel waktu maka semakin tinggi pula nilai variabel biaya (dan sebaliknya).

Dari interpretasi di atas, diketahui masing-masing dari variabel pergerakan komuting memiliki hubungan korelasi yang searah satu sama lain. Hal ini dapat diinterpretasikan bahwa apabila salah satu variabel mempunyai nilai tinggi maka variabel-variabel lain akan turut mengalami peningkatan jumlah nilai.

Metode analisa tabulasi silang akan membandingkan variabel moda dengan variabel jarak tempuh, waktu tempuh, dan biaya perjalanan. Metode crosstab digunakan dikarenakan variabel moda kendaraan memiliki data nominal yang tidak dapat diolah dalam analisa korelasi Pearson. Sebelumnya, variabel selain moda telah diolah menjadi data nominal untuk menyesuaikan dengan data moda kendaraan. Proses analisa ini menggunakan SPSS Statistics 17.0.

Dari chi-square test pada Tabel 9, diketahui nilai signifikansi dari kedua variabel ini ialah 0,593 yang berarti $>0,05$. Artinya Ho diterima dan Ha ditolak. Maka dapat disimpulkan tidak adanya hubungan antara variabel jarak tempuh dengan moda kendaraan.

Dari chi-square test pada Tabel 10, diketahui nilai signifikansi dari kedua variabel ini ialah 0,535 yang berarti $>0,05$. Artinya Ho diterima dan Ha ditolak. Maka dapat disimpulkan tidak adanya hubungan antara variabel waktu tempuh dengan moda kendaraan.

Dari chi-square test pada Tabel 11, diketahui nilai signifikansi dari kedua variabel ini ialah 0,000 yang berarti $<0,05$. Artinya Ho ditolak dan Ha diterima. Selain itu diketahui koefisien kontingensi sejumlah 0,506 yang menunjukkan adanya hubungan yang cukup di antara kegua variabel tersebut. Maka dapat disimpulkan adanya hubungan yang signifikan antara biaya perjalanan dengan moda kendaraan.

Berdasarkan analisa yang telah dilakukan diketahui 2 interpretasi atas hubungan di antara variabel-variabel pergerakan komuting. Interpretasi tersebut ialah sebagai berikut:

1. Variabel jarak tempuh, waktu tempuh dan biaya perjalanan memiliki hubungan yang searah, artinya 
Tabel 10.

Analisa Crosstab Waktu dengan Moda Kendaraan

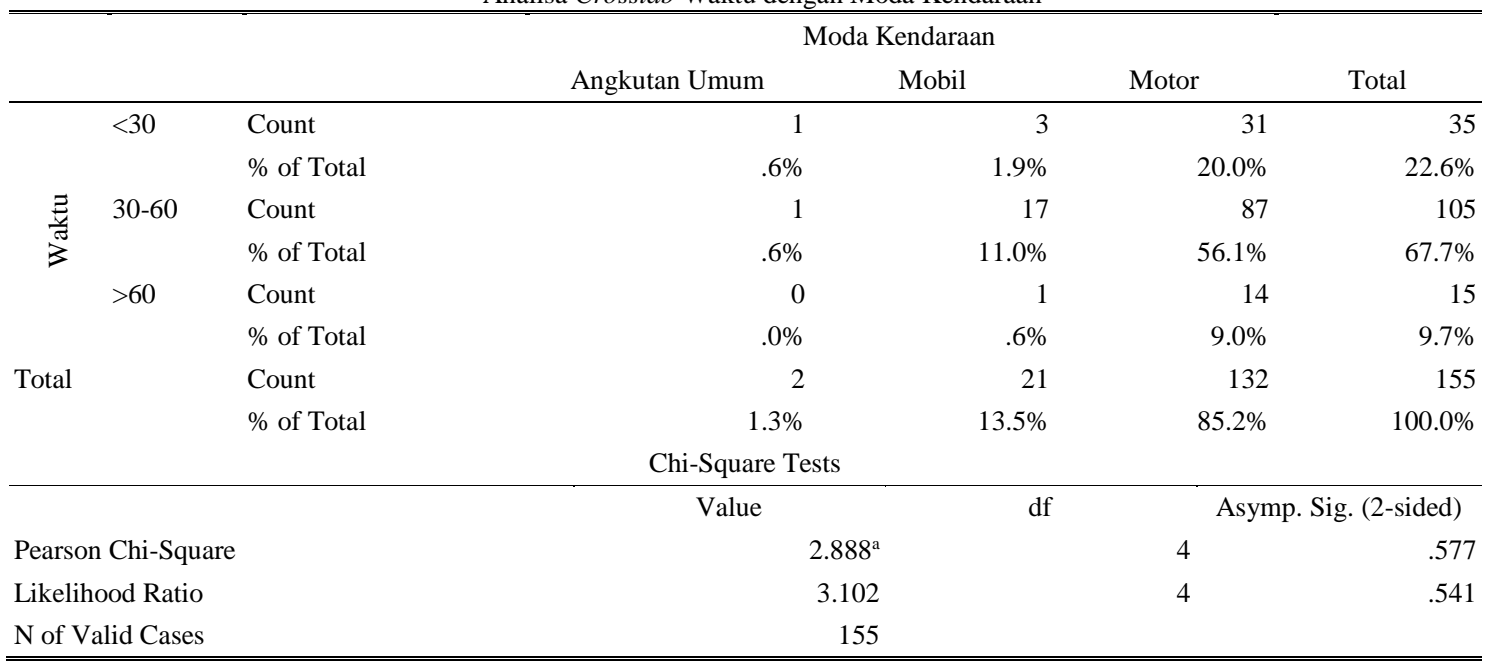

Tabel 11.

Analisa Crosstab Biaya dengan Moda Kendaraan

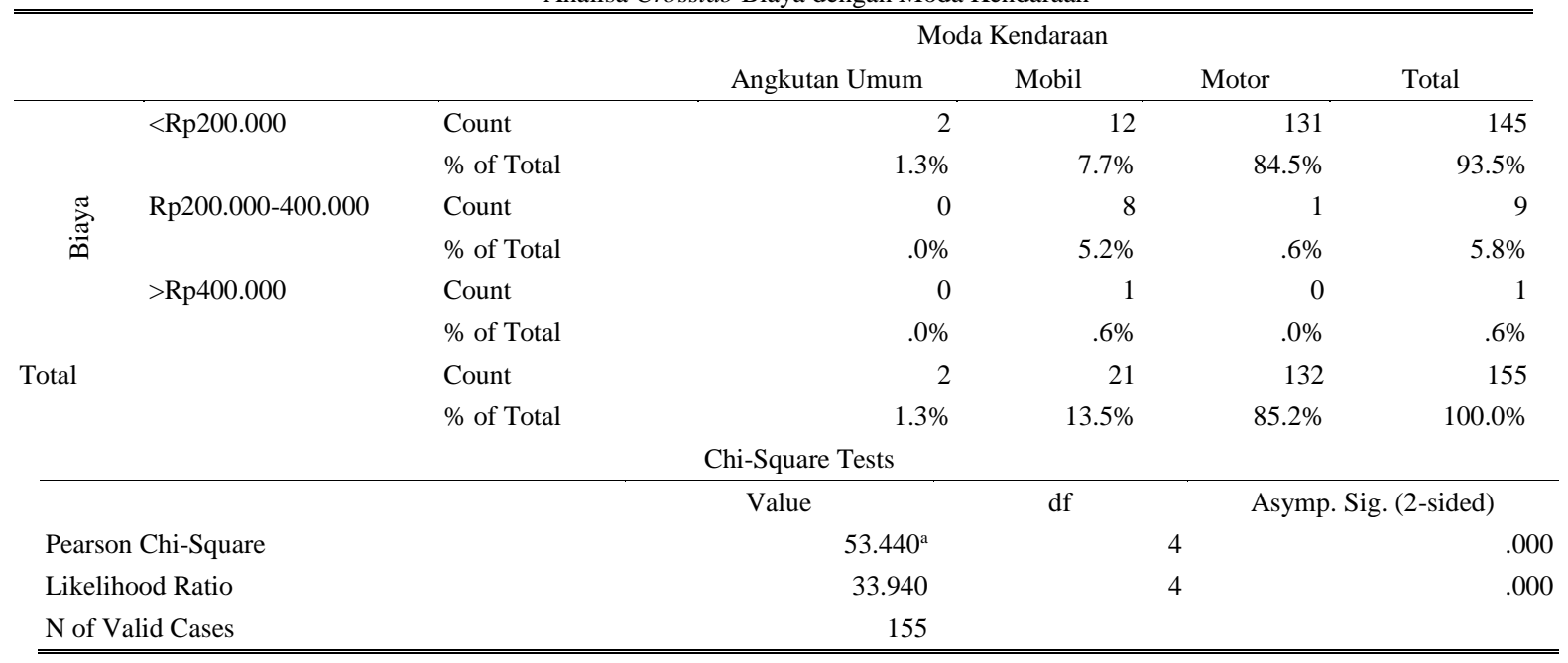

semakin tinggi nilai dari salah satu variabel tersebut maka semakin tinggi pula nilai milik dua variabel lainnya.

2. Variabel moda kendaraan tidak memiliki hubungan yang signifikan terhadap variabel jarak dan waktu, namun terdapat hubungan signifikan terhadap variabel biaya perjalanan. Artinya pemilihan moda kendaraan pelaku komuting dipengaruhi oleh besarnya biaya perjalanan yang dapat dikeluarkan oleh masing-masing individu.

\section{KESIMPULAN/RINGKASAN}

Dari penelitian yang telah dilakukan, dapat ditarik beberapa kesimpulan dan saran sebagai berikut :

1. Berdasarkan 155 data responden yang telah dihimpun, pergerakan komuting dari wilayah studi terdistribusi menuju 25 Kecamatan di Kota Surabaya, yaitu Kecamatan Benowo, Bubutan, Dukuh Pakis, Gayungan, Genteng, Gubeng, Jambangan, Kenjeran, Krembangan, Lakarsantri, Mulyorejo, Pabean Cantian, Rungkut, Sambikerep, Sawahan, Semampir, Sukolilo, Sukomanunggal, Tambaksari, Tandes, Tegalsari, Tenggilismejoyo, Wiyung, Wonocolo dan Wonokromo.

2. Pergerakan komuting yang terjadi di Sidoarjo-Surabaya mayoritas menuju ke Kecamatan Genteng. Jarak tempuh pergerakan komuting tertinggi berada di
Kecamatan Sukodono, waktu tempuh tertinggi pergerakan komuting dari Kecamatan Taman dan biaya perjalanan tertinggi pergerakan komuting dari Kecamatan Sedati.

3. Penggunaan moda kendaraan didominasi oleh sepeda motor yang dapat diinterpretasikan bahwa pelaku komuter masih memilih menggunakan kendaraan pribadi dibanding transportasi publik. Hal ini dapat disebabkan keterbatasan opsi transportasi publik yang hanya berupa kereta komuter dan angkutan umum dengan rute dan jadwal perjalanan yang belum optimal.

4. Adanya hubungan yang searah antara variabel jarak tempuh, waktu tempuh dan biaya perjalanan. Maka semakin besar nilai salah satu di antara variabel tersebut maka akan semakin besar pula nilai variabel lainnya.

5. Adanya hubungan yang berpengaruh antara moda kendaraan dengan biaya perjalanan. Diketahui bahwa penduduk yang menggunakan moda kendaraan mobil cenderung mengeluarkan biaya perjalanan yang tinggi pula

\section{DAFTAR PUSTAKA}

[1] BPS Kota Surabaya, "Data Jumlah Tenaga Kerja di Kota Surabaya Tahun 2006," 2016.

[2] BPS Kota Surabaya, "Data Jumlah Populasi Penduduk Kota Surabaya 
tahun 2018," 2019

[3] F. Raeka, "Model Perkembangan Nilai Lahan Perkotaan Surabaya," Surabaya, 2012.

[4] BPS Kabupaten Sidoarjo, "Data Jumlah Populasi Penduduk Kabupaten Sidoarjo tahun 2018," Sidoarjo, 2019.

[5] Pemerintah Kabupaten Sidoarjo, "BAB VII Rencana Pola Ruang Wilayah Kabupatebn Sidoarjo," Sidoarjo, 2009.

[6] R. Sijabat and A. Rakhmasari, "Model Pemilihan Moda Pergerakan Komuter di Kecamatan Sayung," 2013.

[7] K. Boussaw, F. Witlox, and T. Neutens, "Relationship between Spatial Proximity and Travel-to-Work Distance: The Effect of Compact City,"
Belgium, 2010.

[8] Dinas Komunikasi dan Informatika Kabupaten Sidoarjo, "Jumlah Tenaga Kerja menurut Tempat Bekerja. Indikator Tenaga Kerja Kabupaten Sidoarjo tahun 2018," 2018.

[9] Dinas Perhubungan Kabupaten Sidoarjo, "Data LOS Jaringan Jalan Kabupaten Sidoarjo. Masterplan Transportasi Tahap II Kabupaten Sidoarjo 2015," 2015.

[10] S. Anwar, Metode Penelitian. Yogyakarta: Pustaka Pelajar, 2010.

[11] Suparto, "Analisis Korelasi Variabel-Variabel yang Mempengaruhi Siswa dalam Memilih Perguruan Tinggi," Surabaya, 2014.

[12] M. Zukipli, "Metode Analisis Tabulasi Silang (Crosstabs)," 2009. 